\title{
The effect of thiamine deficiency on inflammation, oxidative stress and cellular migration in an experimental model of sepsis
}

José Antenor Araújo de Andrade ${ }^{1 \dagger}$, Carlos Roberto Machado Gayer ${ }^{2}$, Natália Pereira de Almeida Nogueira ${ }^{2}$, Márcia Cristina Paes ${ }^{2+}$, Vera Lúcia Freire Cunha Bastos ${ }^{2+}$, Jayme da Cunha Bastos Neto ${ }^{2+}$, Sílvio Caetano Alves $\mathrm{Jr}^{3}$, Raphael Molinaro Coelho ${ }^{3}$, Mariana Gysele Amarante Teixeira da Cunha ${ }^{3}$, Rachel Novaes Gomes ${ }^{3 \dagger}$, Márcia Barbosa Águila ${ }^{4 \dagger}$, Carlos Alberto Mandarim-de-Lacerda ${ }^{4 \dagger}$, Patrícia Torres Bozza ${ }^{3+}$ and Sérgio da Cunha ${ }^{1 * \dagger}$

\begin{abstract}
Background: Sepsis is a prevalent condition in critically ill patients and may be associated with thiamine deficiency (TD). The aim of this study was to evaluate the effect of TD on inflammation, oxidative stress and cellular recruitment in a sepsis model.

Methods: The experimental sepsis model, cecal ligation and puncture (CLP), was utilized on mice in comparison with a sham procedure. The following four groups were compared against each other: SHAM with AIN93G complete chow, SHAM with thiamine deficient (TD) chow, CLP with AIN93G complete chow, and CLP with TD chow. Thiamine pyrophosphate (TPP) blood concentrations were determined, and blood and peritoneal fluid were evaluated for differences in TNF-alpha, IL-1, IL-6, KC and MCP-1/CCL2 levels. In addition, the levels of 4-HNE adducts in liver proteins were evaluated by Western Blot.
\end{abstract}

Results: The mean TPP blood concentration from the mice fed with the complete chow was $303.3 \pm 42.6 \mathrm{nmol} / \mathrm{L}$, and TD occurred within 10 days. TNF- $a$ and MCP-1 concentrations in the peritoneal fluid were significantly greater in the CLP with TD chow group when compared with the other groups. The blood IL-1 $\beta$ level, however, was lower in the CLP with TD chow group. Liver 4-HNE levels were highest in the TD chow groups. Blood mononuclear cell numbers, as well as peritoneal total leukocyte, mononuclear cell and neutrophil numbers were greater in the CLP with TD chow group. Peritoneal bacterial colony forming units (CFU) were significantly lower in the CLP with TD chow group.

Conclusion: TD was associated with greater bacterial clearance, oxidative stress and inflammatory response changes.

Keywords: Thiamine, Sepsis, Oxidative stress, Inflammation, Sepsis model

\section{Background}

Several clinical conditions, such as trauma, burn, severe acute illness and major postoperative surgery generate a series of organic response reactions in response to these injuries, called the systemic inflammatory response syndrome (SIRS). When SIRS is associated with an infection, it is defined as sepsis [1-3]. Epidemiological studies worldwide [4-6] and in Brazil $[7,8]$ indicate that sepsis is a

\footnotetext{
* Correspondence: sergio.d.cunha@gmail.com

${ }^{\dagger}$ Equal contributors

'Intensive Care Unit, Pedro Ernesto University Hospital, State University of Rio de Janeiro, Av. 28 de Setembro 87, Rio de Janeiro, RJ CEP 20551-030, Brazil Full list of author information is available at the end of the article
}

prevalent condition with a high mortality rate that is associated with the emergence of multidrug-resistant pathogens $[9,10]$ while also generating high social and financial costs [11]. Thiamine (vitamin B1) is a water soluble vitamin that does not accumulate in the body; therefore, it has to be ingested daily [12]. Thiamine pyrophosphate (TPP; the biologically active form of vitamin B1) is an important mitochondrial enzyme cofactor [12] with a key role in energy balance. In addition, TPP participates as a transketolase cofactor in the pentose phosphate pathway, a pathway that replenishes NADPH, which is necessary for the recovery of the reduced form of glutathione (GSH) from its oxidized form. TPP is also a cofactor of the $\alpha$-ketoglutarate

\section{Biomed Central}

(c) 2014 de Andrade et al.; licensee BioMed Central Ltd. This is an Open Access article distributed under the terms of the Creative Commons Attribution License (http://creativecommons.org/licenses/by/2.0), which permits unrestricted use, distribution, and reproduction in any medium, provided the original work is properly credited. 
dehydrogenase complex [12], theoretically participating in the recovery of cellular reducing power [13].

The prevalence of TD in critically ill patients has been described [14-16] and was associated with increased morbidity and mortality [16]. Recent studies have demonstrated that additional attention is needed in the identification of thiamine deficiency (TD) and that thiamine supplementation is necessary not only in intensive care unit patients but also in patients with heart failure $[15,17,18]$.

Evidence that TD may cause heart failure has been demonstrated $[12,19,20]$, whereby an increase in oxidative stress due to TD led to the apoptosis of cardiomyocytes [21] and produced cardiac remodeling [20,22]. Structural remodeling and the destruction of cardiomyocyte mitochondria were also observed with TD [20]. A similar finding was observed in a study with human neuroblastoma cells cultured under TD conditions [23].

Several neurological disorders have been associated with $\mathrm{TD}$, including acute confusion and changes in eye movement and gait (Wernicke's encephalopathy). These findings may be associated with chronic memory impairment (Korsakoff's syndrome) [12,24,25]. Thiamine deficiency may also be associated with brain degenerative conditions such as Parkinson's disease and Alzheimer's disease [24-27]. Thiamine deficiency is also associated with lesions of the endoplasmic reticulum of neurons [28]. The influence of TPP in an experimental model of sepsis in dogs has recently been performed [29], and the following outcomes were analyzed: blood $\mathrm{pH}$, oxygen consumption, base excess, mean arterial pressure and the cardiac index. The authors observed recovery of all of these parameters in the animals treated with TPP, suggesting the involvement of thiamine as a possible protective agent against the onset of sepsis.

Sepsis is associated with an intense inflammatory response [30]. In response to an injury, the initial inflammatory response is the activation of the innate immunity pathways. The innate inflammatory response is a series of "primitive" non-specific reactions that occur in the early hours after the interaction with a pathogen and involve acute phase proteins, the complement system, dendritic cells, macrophages and natural killer cells (NK), with the end result being inflammation [31-34]. When an activated macrophage comes into contact with a pathogen, it begins to produce TNF- $\alpha$, which is responsible for an increase in vascular permeability. In addition, pathogen stimulation of macrophages leads to the production of IL- $1 \beta$ and IL-6, which have decisive roles in the genesis of fever by acting on the central hypothalamic temperature control system [34]. The chemotactic factors KC and MCP-1 are involved in the recruitment of neutrophils and monocytes, respectively, and are involved in the perpetuation of the cellular response to injury. In parallel, IL-10 secretion is a self-regulatory mechanism of the inflammatory response, acting as an anti-inflammatory cytokine [30,31].

The cellular injury observed in sepsis produces highly reactive biochemical intermediates from nitrogen and oxygen [35]. Following an injury, we now know that the increased production of reactive oxygen species (ROS) and the increased activity of clearance mechanisms do not necessarily indicate cell damage $[35,36]$. ROS have the ability to react with proteins, lipids, and genetic material. The products of these reactions are known today and include 4-hydroxy 2-nonenal (4-HNE), an aldehyde that results from the lipid peroxidation of the cell membrane [37]. 4-HNE plays a key role in cell signaling and redox balance $[38,39]$, but in high concentrations, it can be harmful to cells [37-39].

Experimental sepsis models are necessary to evaluate some aspects of this clinical condition, due to ethical constraints [40-42]. Many methods are used to simulate hemodynamic, immunological and clinical sepsis events, including surgical manipulation of organs (such as ligation or perforation of the bowel loops) [42] and injection of bacteria or their components (e.g., endotoxins, such as gramnegative lipopolysaccharides) into the bloodstream [41], organs and anatomical cavities. These methods are not free of criticisms from both a methodological standpoint $[43,44]$ and from technical and ethical standpoints, with regard to animal handling [45]. These experimental models, however, represent important tools for sepsis investigation.

This study analyzed the possible effect of thiamine deficiency on changes in sepsis markers of inflammation (cytokines), the balance of the oxidation-reduction system (based on the presence of a marker of lipid peroxidation), and the leukocyte recruitment profile. The hypothesis in question was that thiamine deficiency in experimental sepsis conditions could result in a pro-inflammatory profile, with greater oxidative stress and cellular migration.

\section{Methods}

This study was approved by the ethics committee for the use of animals for research at the Roberto Alcântara Gomes Biology Institute - UERJ (CEUA/036/2011).

\section{Animals and chow}

Sixty-five male C57bl6 mice (Cecal - FIOCRUZ, Rio de Janeiro, RJ, Brazil), between 6 and 8 weeks old, were maintained in groups of 5 per cage, with free access to water and food. The mice were exposed to a 12-hour light cycle (lights off until 6 a.m. and a controlled temperature $\left(24^{\circ} \mathrm{C} \pm 2^{\circ} \mathrm{C}\right)$. Two types of chow were used for the study (Pragsoluções Biociências, Jaú, SP, Brazil). The first type of chow contained all of the components of a normal AIN93G chow [46]. The second chow type was similar to the AIN93G chow but without the addition of thiamine. Before each experiment, all groups were fed 
with the AIN93G chow for one week to standardize the thiamine intake. Throughout the study, the animal's body weight and chow intake were measured.

\section{Determining the time required for TD}

To determine the time required to produce a TD, mice were divided into five groups (five animals per group). Initially, all groups were fed with the AIN93G chow for seven days to standardize the thiamine intake. The control group was sacrificed after seven days, and blood was collected for determination of the circulating thiamine levels by High Performance Liquid Chromatography (HPLC). The other four groups were fed with the thiamine deficient AIN93G chow for an additional 10, 15, 20 and 25 days before euthanasia, and blood samples were collected for HPLC analyses. We determined the normal concentration of TPP in C57bl6 mice, which is information that was not found in prior studies. Thiamine deficiency was defined as a TPP blood concentration lower than two standard deviations below the mean.

\section{The experimental sepsis procedure}

For the experimental sepsis model experiments, forty mice were divided into 4 groups (10 animals per group), and the duration of the each experiment was 15 days. The experimental groups were as follows: 1 ) a control group fed with the AIN93G complete chow that was subjected to laparotomy without cecal ligation and puncture - CLP (sham); 2) a group fed with the AIN93G complete chow that was subjected to laparotomy and CLP; 3) a group fed with the thiamine deficient AIN93G chow that was subjected to laparotomy without CLP; and 4) a group fed with the thiamine deficient AIN93G chow and subjected to laparotomy and CLP. For all groups, euthanasia was performed 24 hours after surgery to collect liver and blood samples.

The animals were anesthetized by intraperitoneal injection of ketamine $(65 \mathrm{mg} / \mathrm{kg})$ and xylazine $(13 \mathrm{mg} / \mathrm{kg})$ (Vetbrands Brazil, Campinas, SP, Brazil). A cutaneous abdominal incision was made longitudinally and medially, approximately 2 centimeters in length, followed by opening of the peritoneum and cecum identification. The cecum was then ligated to form a closed intestinal loop and was perforated two times by an 18 gauge needle. The closed loop was gently compressed to expose the abdominal cavity to feces, and then the intestinal loop was placed back into the abdominal cavity. The peritoneum and skin were then sutured closed. Sham-operated mice were subjected to identical procedures, except the cecum ligation and puncture steps were omitted. After surgery, a sterile saline subcutaneous injection was given for fluid replacement $[42,47]$. Euthanasia was performed by an injection of double the amount of anesthetic that was calculated for each animal during the CLP or sham surgeries. Following euthanasia, a blood sample was collected and the abdomen was opened for liver removal.

\section{Blood sample preparation for HPLC}

The blood samples were preserved by refrigeration and processed on the same day of collection. Whole blood was frozen three times in liquid nitrogen to complete hemolysis and was then centrifuged at 14,000 rcf. Then, after thirty minutes of rest, the liquid phase was collected and deproteinated by the addition of $40 \%$ trichloroacetic acid (TCA). The TCA was then extracted with five volumes of watersaturated ethylic ether. To form the thiamine thiochrome derivatives, the lower watery fraction was collected and derivatized by adding $50 \mu \mathrm{L}$ of potassium ferricyanide $(30.4 \mathrm{mmol} / \mathrm{L})$ and $50 \mu \mathrm{L}$ of sodium hydroxide $(0.8 \mathrm{~mol} / \mathrm{L})$ for each $1,000 \mu \mathrm{L}$ aliquot of blood. The final sample was frozen at $-70^{\circ} \mathrm{C}$ for later analysis by HPLC [20].

\section{The determination of TPP by HPLC/fluorescence}

After derivatization, $100 \mu \mathrm{L}$ of the final sample was injected into a Hypersil Gold Amino column (Thermo, USA) $(250 \times 4.6 \mathrm{~mm}, 5 \mu \mathrm{m}$ particle $)$. The shimadzu HPLC system (Shimadzu, Kyoto, Japan) consisted of a LC-10 AD pump valve 535, and a fluorimetric RFdetection method was utilized, based on the excitability of the thiochrome to fluorescent light.

The mobile phase (isocratic), with $30 \%$ acetonitrile in a potassium phosphate buffer (0.1 M, pH 7.5), was pumped at a flow rate of $1.0 \mathrm{~mL} / \mathrm{min}$. The fluorimetric detection occurred at $450 \mathrm{~nm}$ emission and $370 \mathrm{~nm}$ excitation wavelengths $[20,48]$. Standards equivalent to $4.6875,9.375$, $18.75,37.5,75,150,300$ and $600 \mathrm{nmol} / \mathrm{L}$ were prepared for the construction of calibration curves.

\section{The assessment of 4-HNE in the liver by western blot}

About $100 \mathrm{mg}$ of hepatic tissue were homogenized in $500 \mu \mathrm{l}$ of lysis buffer (50 mM HEPES, $1 \mathrm{mM} \mathrm{MgCl} 2,1 \%$ Triton X-100, 0.1\% SDS, 10 mM EDTA; pH 6.4), containing protease inhibitor cocktail Sigma-Adrich Fine Chemicals (1.04 mM AEBSF, $800 \mathrm{nM}$ aprotinin, $20 \mu \mathrm{M}$ leupeptin, $40 \mu \mathrm{M}$ bestatin, $15 \mu \mathrm{M}$ pepstatin A and $14 \mu \mathrm{M}$ E-64) in ice. Tissue homogenate was centrifuged at $10,000 \mathrm{rpm}$ for $10 \mathrm{~min}$. the pellet was discarded and the supernatants were used for protein quantification by the Peterson's method. Whole protein extracts (about $80 \mu \mathrm{g}$ ) were subjected to electrophoresis in a 15\% SDS-polyacrylamide gel under reducing conditions. Proteins were transferred $(25 \mathrm{mM}$ Tris, $192 \mathrm{mM}$ glicine, $\mathrm{pH} 8.3,20 \%$ methanol) to a nitrocellulose membrane at $4^{\circ} \mathrm{C}$ for $2 \mathrm{~h}$. Membranes were blocked with Tris-buffered saline solution containing $0.1 \%$ Tween 20 (TBS-T) and 5\% bovine serum albumin (BSA). The membranes were then incubated overnight with anti-4-HNE antibody (1:1000), diluted in blocking solution, washed in TBS-T, and finally incubated for $1 \mathrm{~h}$ with horseradish peroxidase-conjugated anti-mouse antibody (1:10.000). The bands were revealed by chemiluminescence using the ECL substrate. Blots were exposed to ECL 

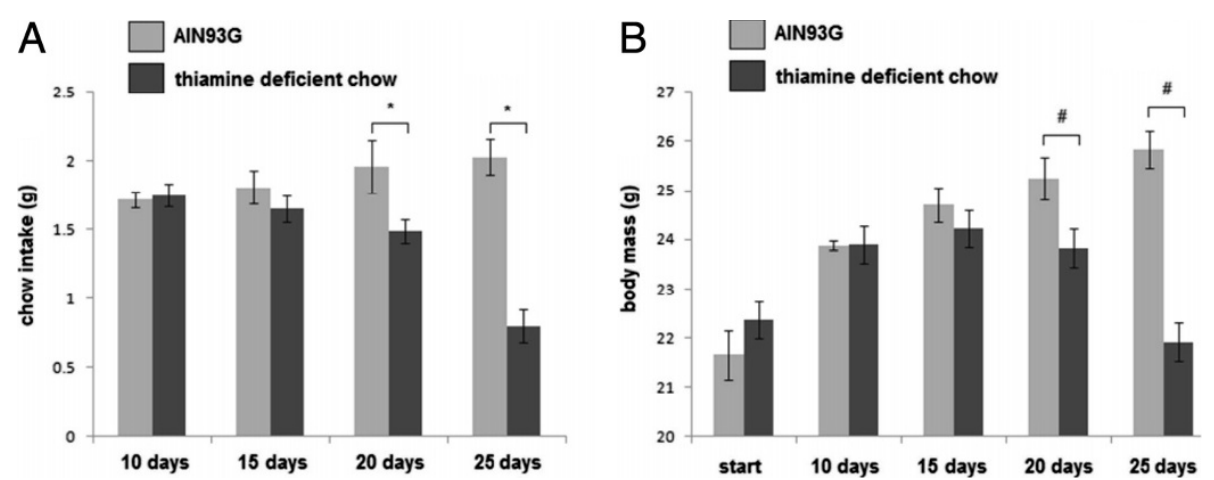

Figure 1 Evolution of food intake and body mass. (A) The food intake was similar between groups in 10 and 15 days. Each bar represents five animals (* $p<0.05)$. (B) Body mass gain was similar between groups in 10 and 15 days, and increased in AIN93G group. Each bar represents five animals (\# $P<0.05$ ). Therefore, until the 15th day the animals had a similar nutritional profile. All data are shown as mean \pm SEM.

Hyperfilm (Amersham) and quantification was performed by densitometric analysis of the exposed films (Adobe Photoshop 5 programme) and the Ponceau S stained membranes were used as a load control [49].

\section{Blood and peritoneal fluid cell counts}

Blood and peritoneal fluid samples were stained with Giemsa stain for total and differential leukocyte counts by optical microscopy at $1,000 \mathrm{x}$ magnification in a Neubauer chamber [47].

\section{Blood and peritoneal fluid cytokine determination}

Determination of the blood and peritoneal fluid TNF- $\alpha$, IL-1, MCP-1/CCL2, IL-6 and KC levels were performed by ELISA (Duo Set Kit - R \& D systems, USA). ELISA plate reading was performed on an ELISA plate reader at $450 \mathrm{~nm}$. The data were analyzed using the Soft Max Pro program, and cytokine concentrations were determined based on their respective standard curves [47].

\section{Peritoneal fluid colony-forming unit counts}

The peritoneal fluid sample colony-forming unit (CFU) counts were obtained by diluting the peritoneal fluid samples 1:50 in sterile PBS, and then the diluted samples were seeded in Petri dishes with TSA growth medium. The plates were incubated at $37^{\circ} \mathrm{C}$ for 24 hours, after

Table 1 Thiamine pyrophosphate whole blood mean concentration

\begin{tabular}{lcc}
\hline & $\begin{array}{c}\text { TPP } \mathrm{nmol} / \mathrm{L} \\
\text { (mean } \pm \text { SEM) }\end{array}$ & $\begin{array}{c}\boldsymbol{p} \text { (compared } \\
\text { to control) }\end{array}$ \\
\hline Control (AIN93G) & $303.3 \pm 19.06$ & - \\
$\mathbf{1 0}$ days of TD chow & $11.93 \pm 1.11$ & $<0.001$ \\
$\mathbf{1 5}$ days of TD chow & $5.01 \pm 0.67$ & $<0.001$ \\
\hline
\end{tabular}

After 10 days of TD chow, the thiamine pyrophosphate whole blood mean concentration was lower than two standard deviations below the mean, what characterizes thiamine deficiency in these animals. which the number of CFUs was counted. The whole procedure was performed under sterile conditions [47].

\section{Statistics analyses}

A two-way ANOVA with a Sidak post-test was used to analyze the differences between the groups for the biochemical, immunological and cellular assays, to perform a multiple comparison analysis between the variables and to evaluate the contribution of each variable. The software used was the Windows version of Prism 6.00 (GraphPad Software, San Diego, CA, USA). The significance level was set at 0.05 [50].

\section{Results}

The body weight evolution and chow intake

The AIN93G chow intake by the mice increased during the experiments; however, the average TD chow intake was reduced significantly by the 20th and 25th days (Figure 1A). The body mass gain of the animals fed with the AIN93G complete chow increased during the first experiment. Body weight loss occurred at the 20th and 25th days in the animals fed with the TD chow (Figure 1B).

\section{Determining the efficiency and time required for TD}

Initially, the time required for TD was determined. Using HPLC, the mean retention times were 3.4 minutes

Table 2 Thiamine pyrophosphate whole blood mean concentration for all groups in sepsis experiment

\begin{tabular}{lcc}
\hline Group & $\begin{array}{c}\text { TPP nmol/L } \\
\text { (mean } \pm \text { SEM) }\end{array}$ & $p$ \\
\hline (1) sham + AIN93G & $383.6 \pm 15.39$ & - \\
(2) sham + TD chow & $41.4 \pm 10.73 \quad<0.001$ (compared to group 1) \\
(3) CPL + AIN93G & $376.9 \pm 12.17$ & - \\
(4) CLP + TD chow & $40 \pm 6.87 \quad<0.001$ (compared to group 3)
\end{tabular}

The groups that were fed with TD chow for 15 days showed significantly lower blood TPP concentrations than groups that were fed with complete chow, profile that was similar to that found in the first experiment. 

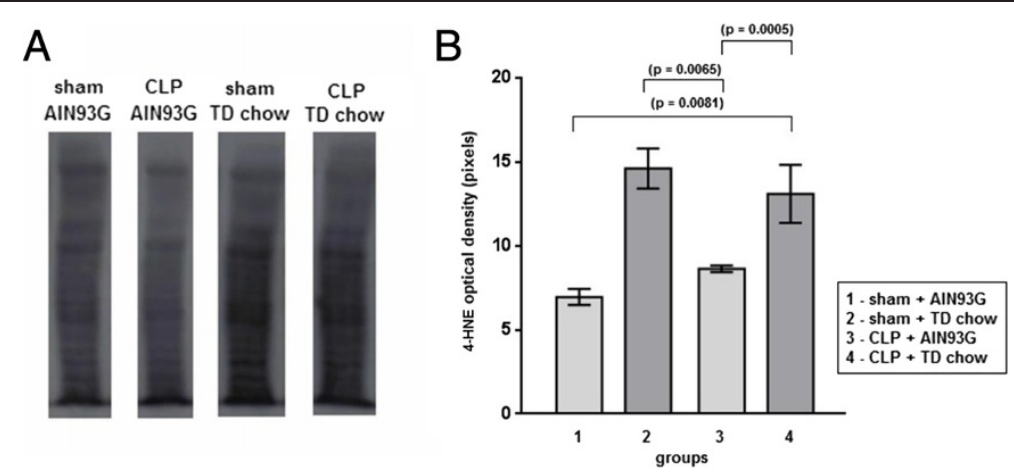

Figure 2 Determination of 4-HNE binding protein in the liver. (A) Western blot detail for each group (the image was sliced). (B) Optical density analysis for each group, showing a significant increase of 4-HNE in TD chow groups without significant difference between the sham and CLP groups. All data (B) are shown as mean \pm SEM.

for free thiamine, 5.3 minutes for thiamine monophosphate, and 6.2 minutes for the TPP. The TPP detection limit was $4.6875 \mathrm{nmol} / \mathrm{L}$. The mean blood TPP concentration in the mice fed the AIN93G complete chow was $303.3 \pm 42.6 \mathrm{nmol} / \mathrm{L}$. Thiamine deficiency was observed at 10 days in the mice fed the TD chow, and the blood concentration of TPP in this group at this time point was $12.5 \pm 2.4 \mathrm{nmol} / \mathrm{L}$ (Table 1 ).

The TPP blood concentrations were also assessed in the sepsis experiments for validation purposes. As shown in
Table 2, both the sham and CLP groups that were fed with TD chow for 15 days showed significantly lower blood TPP concentrations than the sham and CLP groups that were fed with complete chow (Table 2).

\section{Effect of TD on 4-HNE-protein adduct formation}

As shown in Figure 2, we observed an increased level of 4-HNE adducts in liver proteins of TD animals when compared with the animals fed with the AIN93G complete
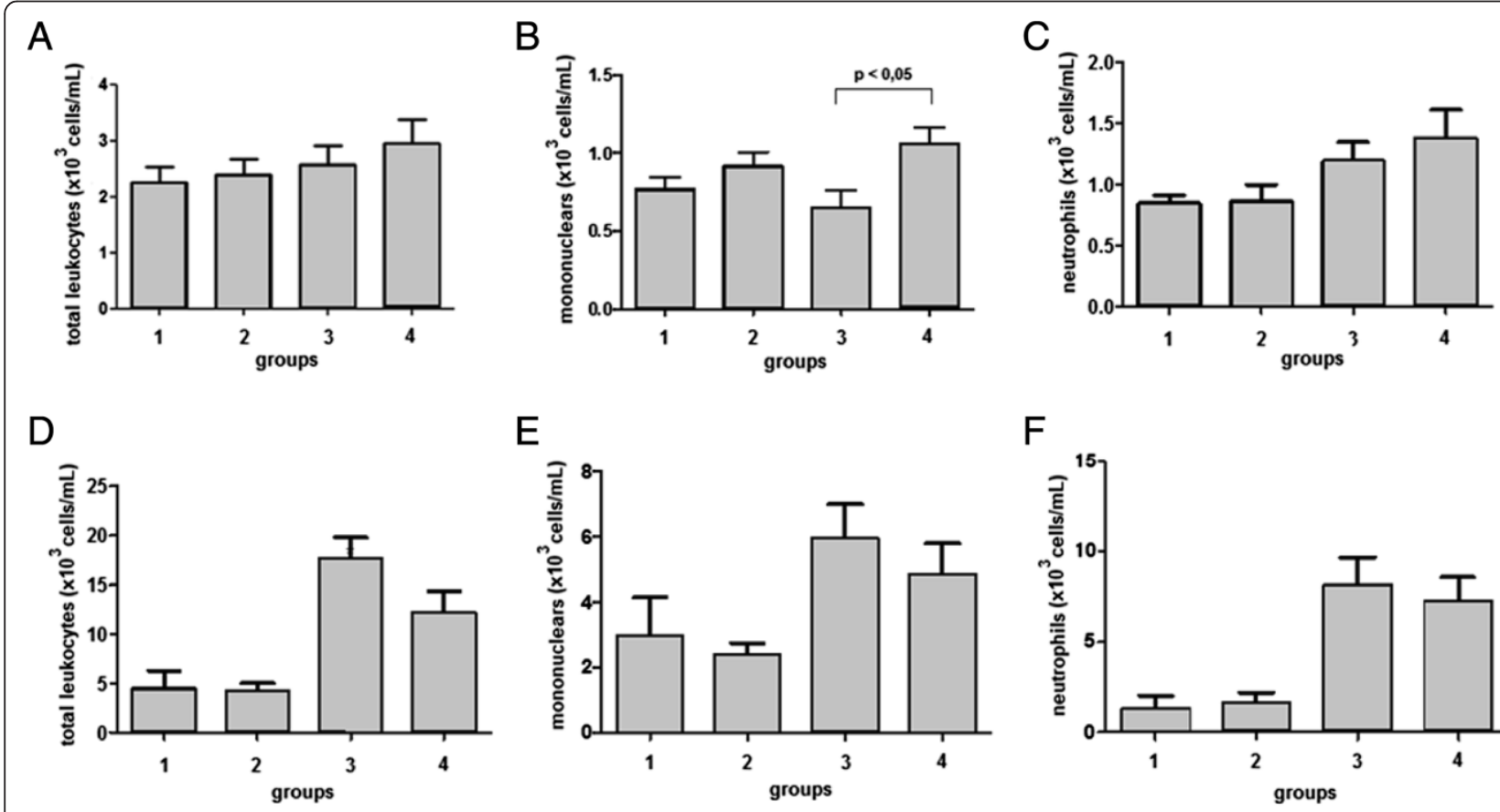

$\mathrm{E}$

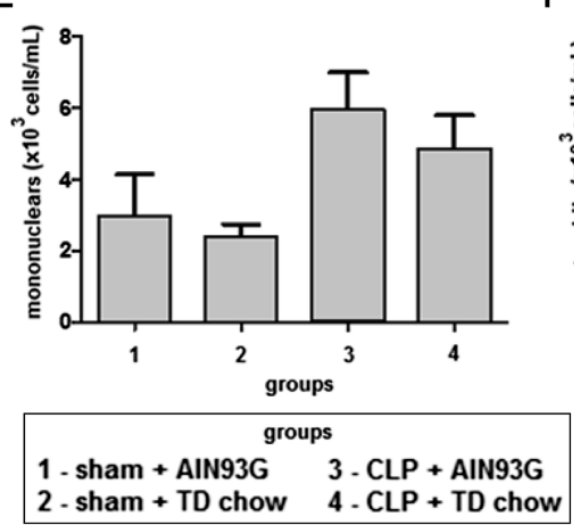

$\mathrm{F}$

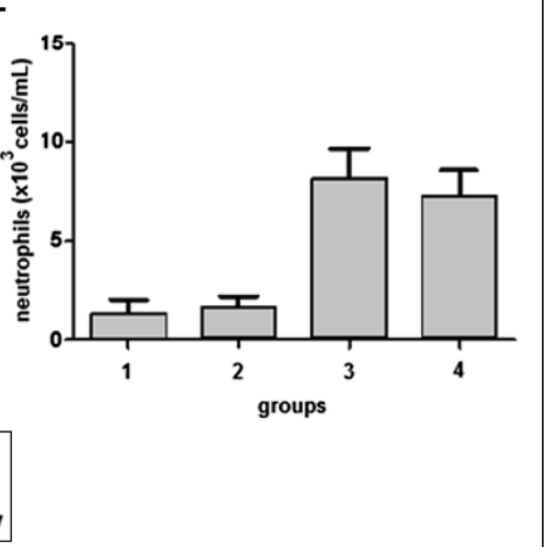

Figure 3 Total number of leukocytes, mononuclears and neutrophils in peripheral blood $(A, B, C)$ and peritoneal fluid $(D, E, F)$.

Mononuclear cell number in the peripheral blood (B) was greater in the CLP group which was fed with the TD chow $(p<0,05)$ but the others cellular types were similar among groups (A - B). In the peritoneal fluid all cellular types were greater in the CLP groups, independent of chow type. 
chow. There was no significant difference between the sham and CLP groups (Figure 2).

\section{Blood and peritoneal fluid cell counts}

The total number of leukocytes and neutrophils in the peripheral blood was similar in all groups. However, the mononuclear cell number in the peripheral blood was greater in the CLP group that was fed with the TD chow (Figure $3 \mathrm{ABC}$ ). In the peritoneal fluid, total leukocyte, mononuclear cell and neutrophil counts were greater in the CLP groups, independent of whether the mice were fed the AIN93G complete or the TD chow (Figure 3 DEF).

\section{Effect of TD on the blood and peritoneal fluid cytokine levels during sepsis}

As shown in Figure 4, $24 \mathrm{~h}$ after CLP, the levels of TNF- $\alpha$, KC, IL-1 $\beta$ and IL-6 were significantly increased when compared with the sham groups. There were no differences in the TNF- $\alpha, \mathrm{KC}$ and IL- 6 blood concentrations when the
CLP with TD chow group was compared with the CLP with AIN93G complete chow group (Figure 4). Interestingly, the IL-1 $\beta$ blood concentration was greater in the groups that were fed the AIN93G complete chow (independent of sham or CLP surgeries) when compared with the TD chow groups ( $\mathrm{p}<0.0001)$ (Figure 4$)$.

In Figure 5, the local peritoneal production of the cytokines was evaluated. The peritoneal concentrations of $\mathrm{KC}$, IL-1 $\beta$ and IL- 6 were greater in the CLP groups, independent of whether the mice were fed the complete or TD chow (Figure 5). Interestingly, the MCP-1 and TNF- $\alpha$ peritoneal fluid concentrations were significantly greater in the CLP groups than in the other groups. Both CLP and TD contributed to the elevation of MCP-1 and TNF- $\alpha$ in the peritoneal fluid (Figure 5).

\section{Peritoneal fluid colony forming unit counts}

The CLP group with AIN93G complete chow displayed a higher bacterial clearance capacity when compared with all
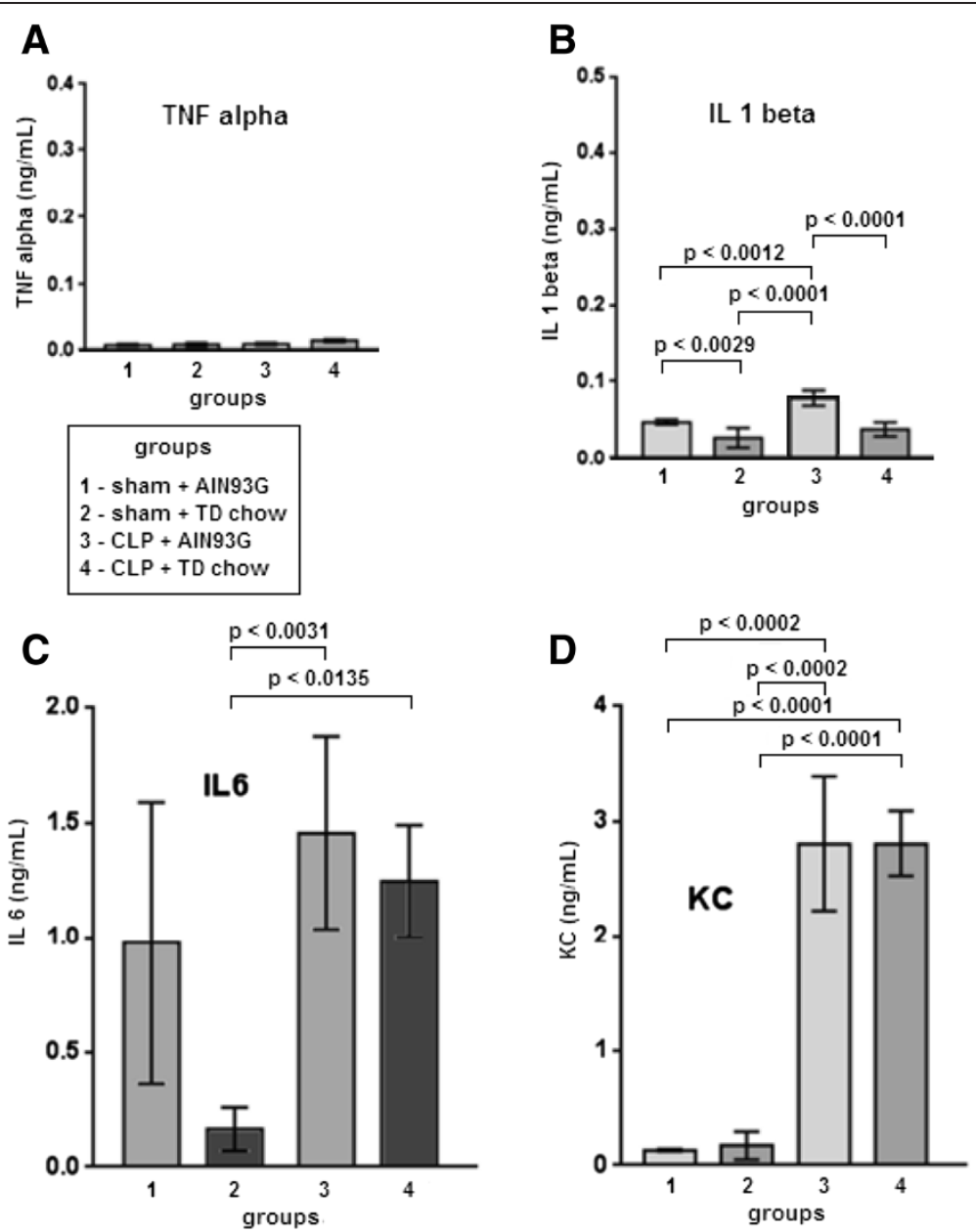

Figure 4 Blood cytokines $\mathbf{2 4} \mathbf{h}$ after CLP. There were no differences in the TNF-a (A) blood concentrations in all groups ( $\mathrm{n}=10$ per group). IL-1 beta blood concentrations (B) were greater in AIN93G groups (independent if sham or CLP) ( $n=10$ per group). IL-6 blood levels (C) tended to be higher in CLP groups ( $n=10$ per group). KC blood levels (D) were higher in CLP groups ( $n=5$ per group). All data are shown as mean \pm SEM. 

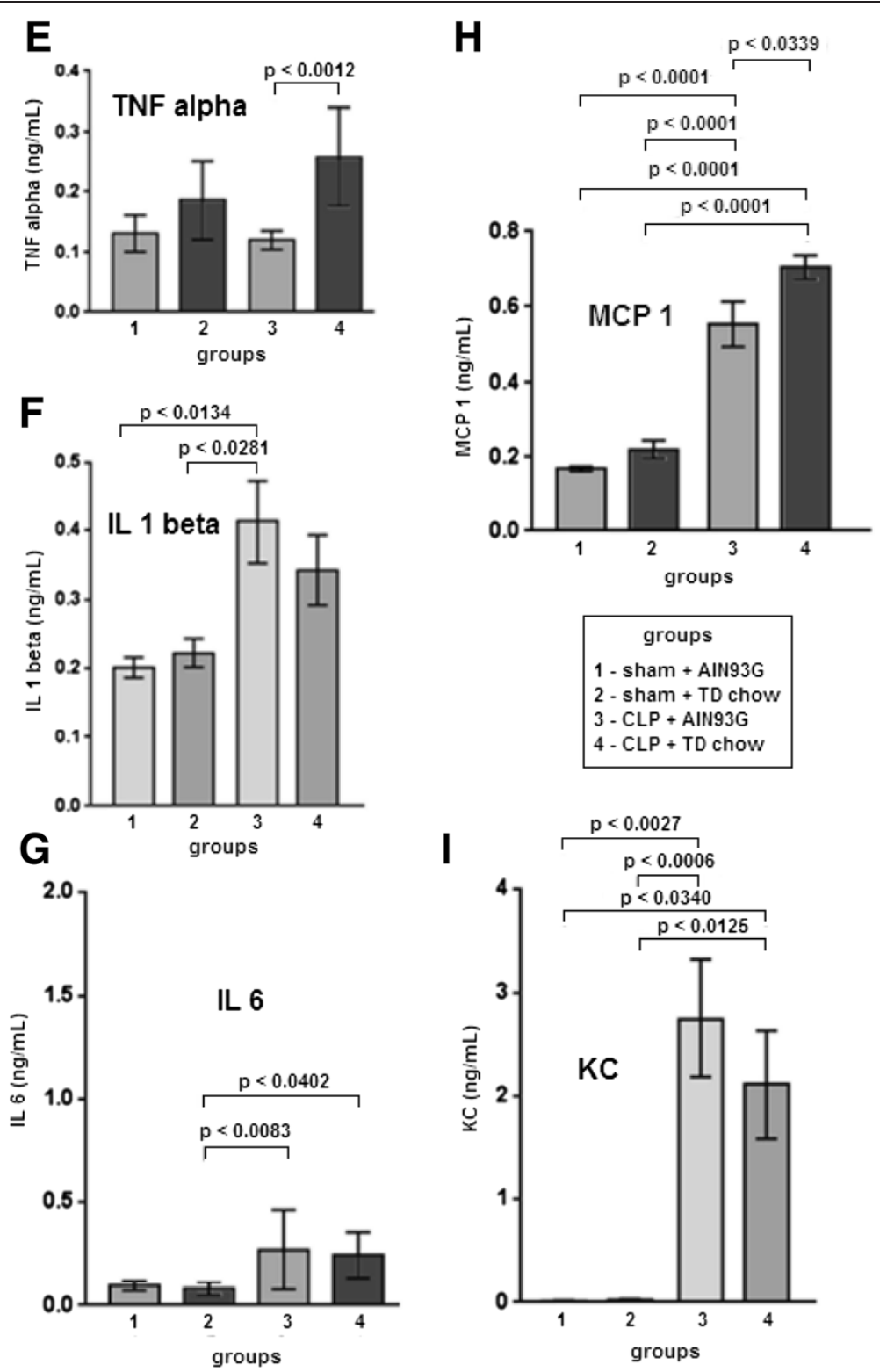

Figure 5 Peritoneal cytokines $\mathbf{2 4} \mathbf{h}$ after CLP. (E) TNF-a peritoneal concentrations were higher in septic animals that were fed with TD chow compared with CLP + AIN93G group ( $n=10$ per group). IL-1 beta (F) $(n=10$ per group), IL-6 (G) $(n=10$ per group) and KC (I) $(n=5$ per group) peritoneal concentrations were higher in CLP groups. MCP-1 $(\mathbf{H})(n=5$ per group) peritoneal concentrations were higher in septic animals that were fed with TD chow compared with all others groups. All data are shown as mean \pm SEM.

of the other groups, including the CLP group fed the TD chow, where the bacterial clearance was equivalent to the sham animal groups (Figure 6).

\section{Discussion}

In this study, we found that mice fed the thiamine deficient AIN93G chow had significantly reduced levels of the biologically active form of thiamine in their serum, providing an experimental condition to assess the effect of thiamine deficiency during sepsis.
First, the normal blood TPP concentration and the number of days necessary for TD induction with TD chow in the mice were determined. Of note, this information had not yet been described in previous research.

The chow intake and mass gain were progressive in the AIN93G complete chow fed animals. In contrast, a decrease in the chow intake and a loss of body weight throughout the study were observed in the mice fed the thiamine deficient chow. This was a profile similar to what was previously described with Wistar rats [20]. 


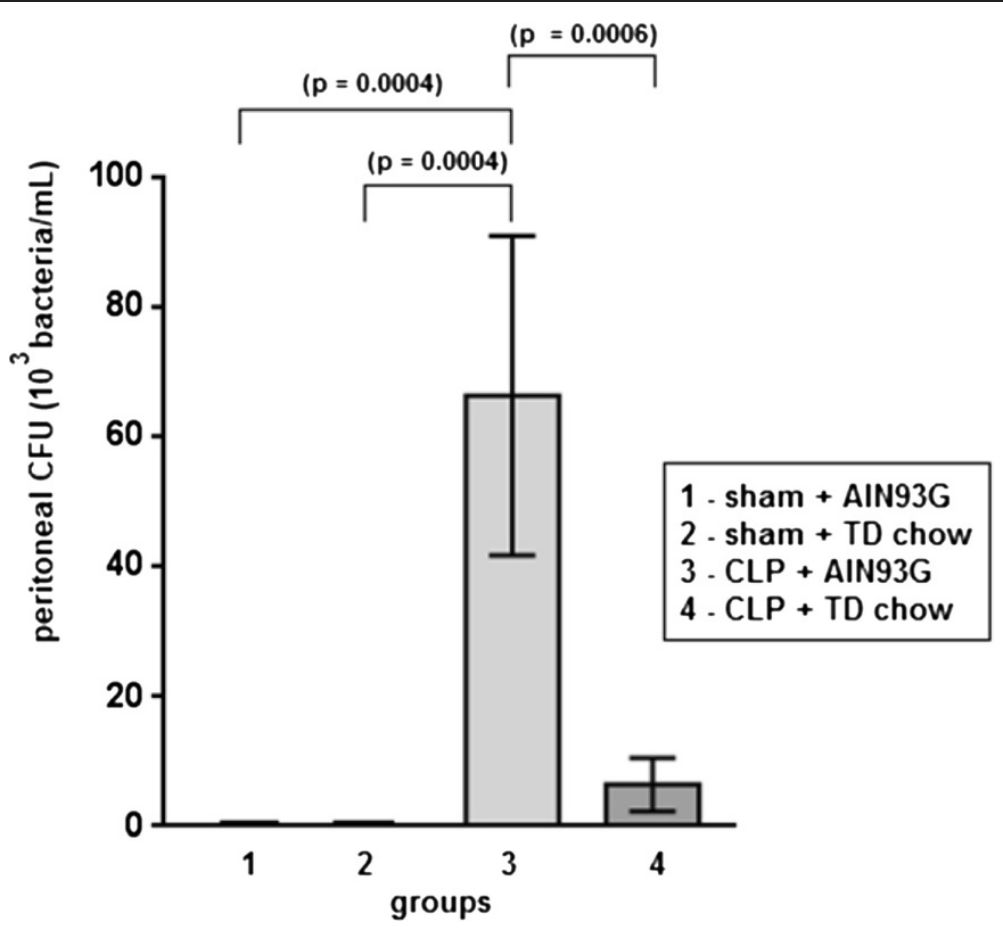

Figure 6 Peritoneal fluid colony forming unit (CFU) counts. The septic group that was fed with TD chow showed a lower bacterial concentration in peritoneal fluid, similar to non-septic groups (sham), but the CLP + AIN93G group showed a higher bacterial concentration in peritoneal fluid, what suggests a higher bacterial clearance capacity of the TD chow group. All data are shown as mean \pm SEM.

Although the animals fed with the thiamine deficient chow for 10 days displayed a significant reduction of TPP in the blood, the decision to carry out the sepsis experiments after 15 days was made to leave no doubt that thiamine deficiency induction had occurred. Because there was no significant difference in the body mass gain and chow intake between the groups on the 15th day, it was not necessary to perform a paired feeding to avoid errors related to ingestion of different amounts of calories, proteins and other nutrients among the groups.

The levels of IL-6, MCP-1 and KC in the blood and of IL-1 $\beta$, IL- 6 and $\mathrm{KC}$ in the peritoneum were not different among the septic groups, independent of their thiamine status. In addition, CLP increased the number of bacteria in the peritoneum, except in the TD group, where the bacterial recovery was similar to that observed in the sham groups.

The level of TNF- $\alpha$ in the peritoneal fluid of the septic animals fed with TD chow was significantly greater than that observed in the other groups. TNF- $\alpha$ is a cytokine of the early innate inflammatory response. It is produced within the first hour of injury, with a peak between the second and third hours following injury. For this reason, it is not usually used in the monitoring of septic patients [51] because the timing of the peak TNF- $\alpha$ level may have already passed when these patients are first evaluated. However, TNF- $\alpha$ is an early marker of inflammation commonly used in sepsis models [47]. TNF- $\alpha$ is a marker of the activity of NK cells and macrophages and may help explain the increased bacterial clearance in the peritoneal fluid that was observed in the CLP mice fed the TD chow used in this study. In addition, we observed a persistent high level of TNF- $\alpha$ in the peritoneal fluid of the CLP mice fed the TD chow, although the number of total leukocytes, monocytes and neutrophils in the peritoneal fluid was similar between the septic animals, independent of their thiamine status. This finding suggests that TD may not change cellular recruitment into the peritoneal cavity following sepsis and that another mechanism may be involved in the increased peritoneal bacterial killing observed in the CLP group fed with TD chow, possibly mediated by TNF- $\alpha$.

Lipid peroxidation is one of the hallmarks of the oxidative stress. Lipid peroxides are usually decomposed into reactive aldehydes such as malondialdehyde (MDA) and 4-hydroxy-2-nonenal (4-HNE), which are also reactive oxygen species. Due to its electrophilic properties, the aldehyde 4-HNE forms adducts with cellular proteins [52]. The present study also demonstrated a greater level of liver proteins modified by 4-HNE in the animals subjected to TD chow compared with what was observed in the other groups. This finding was expected, considering that thiamine may be associated with a lower efficiency of cellular reducing power, since enzymes 
such as pyruvate dehydrogenase and $\alpha-\mathrm{KGDH}$ are responsible for increasing NADH levels in the cell, favoring oxidative stress. Thus, one could suppose that thiamine deficiency also creates greater oxidative stress in the peritoneal cavity, therefore potentially inhibiting bacterial proliferation. The increased bacterial clearance that was observed in this study might initially suggest a better outcome against sepsis in these animals; however, the increased inflammation, as was observed with the increased TNF- $\alpha$ levels, may also be detrimental to sepsis outcomes. Indeed, it was reported that following CLP, an increased mortality rate occurred in animals that displayed an unbalanced inflammatory response, despite a greater bacterial clearance [53].

Extending the analysis of inflammation beyond the first 24 hours after the initiation of sepsis may present a more complete picture of the dynamics of the interleukins.

It is important to remember that the model of sepsis used in the present study can be adjusted to induce a low mortality rate, which may also allow for the investigation of thiamine deficiency in the mechanisms of immunologic tolerance.

\section{Conclusions}

TD was associated with a greater bacterial clearance in the peritoneal fluid, greater oxidative stress and a change in the immune response profile in an experimental model of abdominal sepsis in mice. Further investigation is needed to define the impact of these changes on the severity of sepsis, septic mortality, and also to elucidate the participation of other cellular and biochemical mechanisms.

\footnotetext{
Abbreviations

4-HNE: 4-hydroxy 2-nonenal; AIN93G: Kind of animal feed suggested by the American Institute of Nutrition in 1993; CFU: Colony-forming unit; CLP: Cecal ligation and puncture; GSH: Glutathione; HPLC: High performance liquid chromatography; IL-10: Interleukin-10; IL-1beta: Interleukin 1 beta; IL6: Interleukin 6; iNOS: Inducible form of nitric oxide synthase; KC: Keratinocyte chemoattractant; MCP-1/CCL2: Monocyte chemotactic protein-1; NADPH: Nicotinamide adenine dinucleotide phosphate; NK: Natural killer cells; nmol/L: Nanomole per liter; ROS: Reactive oxygen species; SIRS: Systemic inflammatory response syndrome; TCA: Trichloroacetic acid; TD: Thiamine deficiency; TNF-alpha: Tumor necrosis factor alpha; TPP: Thiamine pyrophosphate; alpha-KGDH: Alpha-ketoglutarate dehydrogenase.
}

\section{Competing interests}

The authors declare that they have no competing interest.

\section{Authors' contributions}

Conceived and designed the experiments: JAAA, VLFCB, JCBN, PTB and SC. Performed the experiments: JAAA, CRMG, NPAN, SCAJ, MGATC, RMC, and RNG. Analyzed the data: JAAA, MCP, VLFCB, JCBN, MBAML, CRMG, NPAN, SCAJ, MGATC, RM, RNG, PTB and SC. Contributed reagents/materials/analysis tools: MCP, VLFCB, JCBN, RNG, PTB and CAML. Wrote the paper: JAAA, CAML, PTB, and SC. All the authors have read and approved the final manuscript.

\section{Acknowledgements}

The study was supported by PROAP/CAPES. We thank Lin Machado de Lima, Roosevelt Aguiar Dias and Paulo Roberto Marques for their skillful assistance.

\section{Author details}

${ }^{1}$ Intensive Care Unit, Pedro Ernesto University Hospital, State University of Rio de Janeiro, Av. 28 de Setembro 87, Rio de Janeiro, RJ CEP 20551-030, Brazil. ${ }^{2}$ Biochemistry Department, Biomedical Center, Institute of Biology, State University of Rio de Janeiro, Rio de Janeiro, Brazil. ${ }^{3}$ Immunopharmacology Laboratory, Oswaldo Cruz Institute, Rio de Janeiro, Brazil. ${ }^{4}$ Morphometry, Metabolism \& Cardiovascular Laboratory; Biomedical Center, Institute of Biology, State University of Rio de Janeiro, Rio de Janeiro, Brazil.

Received: 21 July 2013 Accepted: 14 April 2014

Published: 24 April 2014

\section{References}

1. American College of Chest Physicians/Society of Critical Care Medicine: Consensus conference. Definitions for sepsis and organ failure and guidelines for the use of innovative therapies in sepsis. Crit Care Med 1992, 20:864-874.

2. Rivers E, Nguyen B, Havstad S, Ressler J, Muzzin A, Knoblich B, Peterson E, Tomlanovich M: Early goal-directed therapy in the treatment of severe sepsis and septic shock. N Engl J Med 2001, 345:1368-1377.

3. Dellinger RP, Levy MM, Carlet JM, Bion J, Parker MM, Jaeschke R, Reinhart K, Angus DC, Brun-Buisson C, Beale R, Calandra T, Dhainaut JF, Gerlach H, Harvey M, Marini JJ, Marshall J, Ranieri M, Ramsay G, Sevransky J, Thompson BT, Townsend S, Vender JS, Zimmerman JL, Vincent JL: Surviving sepsis campaign: international guidelines for management of severe sepsis and septic shock. Crit Care Med 2008, 36(1):296-327.

4. Engel C, Brunkhorst FM, Bone HG, Brunkhorst R, Gerlach H, Grond S, Gruendling M, Huhle G, Jaschinski U, John S, Mayer K, Oppert M, Olthoff D, Quintel M, Ragaller M, Rossaint R, Stuber F, Weiler N, Welte T, Bogatsch H, Hartog C, Loeffler M, Reinhart K: Epidemiology of sepsis in Germany: results from a national prospective multicenter study. Intensive Care Med 2007, 33(4):606-618.

5. Záhorec R, Firment J, Straková J, Mikula J, Malík P, Novák I, Zeman J, Chlebo $P$ : Epidemiology of severe sepsis in intensive care units in the Slovak Republic. Infection 2005, 33(3):122-128.

6. Angus DC, Linde-Zwirble WT, Lidicker J, Clermont G, Carcillo J, Pinsky MR: Epidemiology of severe sepsis in the United States: analysis of incidence, outcome, and associated costs of care. Crit Care Med 2001, 29:1303-1310.

7. Sales Júnior JAL, David CM, Hatum R, Souza PCSP, Japiassú AM, Cleovaldo TS, Pinheiro CTS, Friedman G, Silva OB, Dias MDA, Koterba E, Dias FS, Piras C, Luiz RR: Sepse Brasil: epidemiological study of sepsis in intensive care units brazilian. Braz J Intensive Care 2006, 18(1):9-17.

8. Silva E, Pedro MA, Sogayar AC, Mohovic T, Silva CL, Janiszewski M, Cal RG, de Sousa EF, Abe TP, de Andrade J, de Matos JD, Rezende E, Assunção M, Avezum A, Rocha PC, de Matos GF, Bento AM, Corrêa AD, Vieira PC, Knobel E: Brazilian Sepsis Epidemiological Study (BASES study). Crit Care 2004, 8(4):251-260.

9. Soriano FG: Sepsis: Celular, Tissue and Organ Alterations In Experimental Model Of Sepsis. Role of Cytokines and Gene Expression. In PhD Thesis. São Paulo University: Medicine School; 2006.

10. Antonelli M, Bonten M, Chastre J, Citerio G, Conti G, Curtis JR, De Backer D, Hedenstierna G, Joannidis M, Macrae D, Mancebo J, Maggiore SM, Mebazaa A, Preiser JC, Rocco P, Timsit JF, Wernerman J, Zhang H: Cardiovascular, infections, pneumonia and sepsis, critical care organization and outcome, education, ultrasonography, metabolism and coagulation. Intensive Care Med 2012, 38(3):345-358.

11. Sogayar AMC, Machado FR, Rea-Neto A, Dornas A, Grion CMC, Lobo SMA: Prospective study to evaluate costs of septic patients in brazilian intensive care units. Pharmacoecon 2008, 26(5):425-434.

12. Butterworth RF: Thiamine. In Modern Nutrition in Health and Disease. 10th edition. Edited by Shils ME. Lippincott: Williams \& Wilkins; 2006:426-433.

13. Mclain AL, Szweda PA, Szweda LI: a-Ketoglutarate dehydrogenase: a mitochondrial redox sensor. Free Radic Res 2011, 45(1):29-36.

14. Donnino MW, Carney E, Cocchi MN, Barbash I, Chase M, Joyce N, Chou PP, Ngo L: Thiamine deficiency in critically ill patients with sepsis. J Crit Care 2010, 25:576-581.

15. Manzanares W, Hardy G: Thiamine supplementation in the critically ill. Curr Opin Clin Nutr Metab Care 2011, 14(6):610-617.

16. Lima LFP, Leite HP, Taddei JAAC: Low blood thiamine concentrations in children upon admission to the intensive care unit: risk factors and prognostic significance. Am J Clin Nutr 2011, 93(1):57-61. 
17. Schoenenberger AW, Schoenenberger-Berzins R, Maur C, Suter M, Vergopoulos A, Erne M: Thiamine supplementation in symptomatic chronic heart failure: a randomized, double-blind, placebo-controlled, cross-over pilot study. Clin Res Cardiol 2012, 101:159-164.

18. Sriram K, Manzanares W, Joseph K: Thiamine in nutrition therapy. Nutr Clin Pract 2012, 27(1):41-50

19. Azizi-Namini P, Ahmed M, Yan AT, Keith M: The role of $B$ vitamins in the management of heart failure. Nutr Clin Pract 2012, 27(3):363-374.

20. Cunha S, Cunha JB, Salles JB, Silva MC, Cunha Bastos VL, MandarimDe-Lacerda CA: Cardiac alterations in furosemide-treated thiaminedeprived rats. J Card Fail 2007, 13(9):774-784.

21. Gioda CR, Barreto TO, Prímola-Gomes TN, De Lima DC, Campos PP, Capettini LS, Lauton-Santos S, Vasconcelos AC, Coimbra CC, Lemos VS, Pesquero JL, Cruz JS: Cardiac oxidative stress is involved in heart failure induced by thiamine deprivation in rats. Am J Physiol Heart Circ Physiol 2010, 298:2039-2045.

22. Wang Y, Cheng J, Chen G, Rob F, Naseem RH, Ngyen L, Johnstone JL, Hill JA: Remodeling of outward $\mathrm{K}+$ currents in pressure-overload heart failure. J Cardiovasc Electrophysiol 2007, 18(2):869-875.

23. Wang JJ, Hua Z, Fentress HM, Singleton CK: JNK1 is inactivated during thiamine deficiency-induced apoptosis in human neuroblastoma cells. J Nutr Biochem 2000, 11:208-215.

24. Hazell AS: Astrocytes are a major target in thiamine deficiency and Wernicke's encephalopathy. Neurochem Int 2009, 55(1):129-135.

25. Hazell AS, Butterworth RF: Update of cell damage mechanisms in thiamine deficiency: focus on oxidative stress, excitotoxicity and inflammation. Alcohol Alcohol 2007, 44(2):141-147.

26. Hirsch JA, Parrott J: New considerations on the neuromodulatory role of thiamine. Pharmacology 2012, 89(1-2):111-116.

27. Karuppagounder SS, Xu H, Shi Q, Chen LH, Pedrini S, Pechman D, Baker H, Beal MF, Gandy SE, Gibson GE: Thiamine deficiency induces oxidative stress and exacerbates the plaque pathology in Alzheimer's mouse model. Neurobiol Aging 2009, 30(10):1587-1600.

28. Wang X, Wang B, Fan Z, Shi X, Ke ZJ, Luo J: Thiamine deficiency induces endoplasmic reticulum stress in neurons. Neuroscience 2007, 144:1045-1056.

29. Lindenbaum GA, Larrieu AJ, CarrolL SF, Kapusnick RA: Effect of cocarboxylase in dogs subjected to experimental septic shock. Crit Care Med 1989, 17(10):1036-1040.

30. Bozza FA, Salluh II, Japiassu AM, Soares M, Assis EF, Gomes RN, Bozza MT, Castro-Faria-Neto HC, Bozza PT: Cytokine profiles as markers of disease severity in sepsis: a multiplex analysis. Crit Care 2007, 11(2):49.

31. Delves RPJ, Roitt D: The immune system - first of two parts. N Engl J Med 2000, 343:37-50.

32. Janeway CA, Medzhitov R: Innate immunity recognition. Annu Rev Immunol 2002, 20:197-216.

33. Cerwenka A, Lanier LL: Natural killer cells, viruses and cancer. Nat Rev Immunol 2001, 1:41-49.

34. Mosser DM, Edwards JP: Exploring the full spectrum of macrophage activation. Nat Rev Immunol 2008, 8:958-969.

35. Andriantsitohaina R, Duluc L, García-Rodríguez JC, GIL-Del Valle L, GuevaraGarcia M, Simard G, Soleti R, Su DF, Velásquez-Pérez L, Wilson JX, Laher I: Systems biology of antioxidants. Clin Sci 2012, 123(3):173-192.

36. Andrades ME, Arian Morina A, Spasić S, Spasojević I: Bench-to-bedside review: sepsis - from the redox point of view. Crit Care 2011, 15(5):230

37. Raza H, John A: 4-Hydroxynonenal induces mitochondrial oxidative stress, apoptosis and expression of glutathione $\mathrm{S}$-transferase A4-4 and cytochrome P450 2E1 in PC12 cells. Toxicol Appl Pharmacol 2006, 216(2):309-318.

38. Zhang Y, Sano M, Shinmolura K, Tamaki K, Katsumata Y, Matsuhashi T, Morizane S, Ito H, Hishiki T, Endo J, Zhou H, Yuasa S, Kaneda R, Suematsu M, Fukuda K: 4Hydroxy-2-nonenal protects against cardiac ischemia-reperfusion injury via the Nrf2-dependent pathway. J Mol Cell Cardiol 2010, 49:576-586.

39. Sano M: Cardioprotection by hormetic responses to aldehyde. Circ J 2010, 74:1787-1793.

40. Wicherman KA, Baue $A E$, Chaudry $\mathrm{H}$ : Sepsis and septic shock - a review of laboratory models and a proposal. J Surg Res 1980, 29:189-201.

41. Remick DG, Peter AW: Evaluation of endotoxin models for the study of sepsis. Shock 2005, 24(1):7-11.

42. Hubbard WJ, Choudhry M, Schwacha MG, Kerby JD, Loring W, Rue I, Chaudry IH: Cecal ligation and puncture. Shock 2005, 24(1):52-57.

43. Esmon CT: Why do animal models (sometimes) fail to mimic human sepsis? Crit Care Med 2004, 32:219-222.
44. Rittirsch D, Hoesel LM, Ward A: The disconnect between animal models of sepsis and human sepsis. J Leukoc Biol 2007, 81:137-143.

45. Machado CJS, Filipecki ATP, Teixeira MO: Current Brazilian law on animal experimentation. Science 2009, 324(5935):1643-1644.

46. Reeves PG, Nielsen FH, Fahey JRGC: AIN-93 purified diets for laboratory rodents: final report of the american institute of nutrition ad hoc writing committee on the reformulation of the ain-76a rodent diet. J Nutr 1993, 123:1939-1951.

47. Gomes RN: Therapeutical Potential Of The Paf Acetilhidrolase (Paf-Ah) In The Control Of Sepsis. In Thesis. Rio de Janeiro: Oswaldo Cruz Institute; 2006.

48. Lu J, Frank EL: Rapid HPLC measurement of thiamine and its phosphate esters in whole blood. Clin Chem 2008, 54(5):901-906.

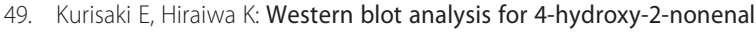
(HNE)-modified proteins in paraquat-treated mice. Legal Med 2009, 11:431-433.

50. Zar J: Biostatistical analysis. 4th edition. Prentice Hall: Upper Saddle River; 1999

51. Bozza FA, Bozza PT, Faria-Neto HC: Beyond sepsis pathophysiology with cytokines: what is their value as biomarkers for disease severity? Mem Inst Oswaldo Cruz 2005, 100:217-221.

52. Catalá A: Lipid peroxidation of membrane phospholipids generates hydroxy-alkenals and oxidized phospholipids active in physiological and/or pathological conditions. Chem Phys Lipids 2009, 157:1-11.

53. Gomes RN, Teixeira-Cunha MG, Figueiredo RT, Almeida PE, Alves SC, Bozza PT, Bozza FA, Bozza MT, Zimmerman GA, Castro-Faria-Neto HC: Bacterial clearance in septic mice is modulated by MCP-1/CCL2 and nitric oxide. Shock 2013, 39(1):63-69.

doi:10.1186/1476-9255-11-11

Cite this article as: de Andrade et al:: The effect of thiamine deficiency on inflammation, oxidative stress and cellular migration in an experimental model of sepsis. Journal of Inflammation 2014 11:11.

\section{Submit your next manuscript to BioMed Central and take full advantage of:}

- Convenient online submission

- Thorough peer review

- No space constraints or color figure charges

- Immediate publication on acceptance

- Inclusion in PubMed, CAS, Scopus and Google Scholar

- Research which is freely available for redistribution

Submit your manuscript at www.biomedcentral.com/submit
C BioMed Central 